\title{
SUSCEPTIBILITY OF SOME FLAX GENOTYPES TO POWDERY MILDEW AND EFFECT OF THE DISEASE ON YIELD AND YIELD COMPONENTS \\ Zayed, S.M.E. ${ }^{1}$; T.A. Abou-Zaid ${ }^{2}$ and M.R. Omar' \\ 1. Plant Pathology Res. Ins., Agric. Res. Center, Giza, Egypt. \\ 2. Field Crops Res. Ins., Agric. Res. Center, Giza, Egypt.
}

\section{ABSTRACT}

A two-year field study was conducted in EL-Gemmeiza Agricultural Research station to : (1) estimate heritability to powdery mildew disease when disease incidence and disease severity were used as criteria to evaluate resistance. (2) assess the susceptibility of 12 flax genotypes to powdery mildew; and (3) determine the effect of the disease on yield and yield components. Disease incidence (DI) and disease severity (DS) were used to evaluate susceptibility of the genotypes to the disease. DI was associated with high heritability and with high genetic advance expected from selection. DS was environmentally unstable. Most of the tested genotypes did not show satisfactory levels of resistance to the disease. However, line 42 / 140 / 5 / 11, line 3 and cultivar Sakha3 were the least susceptible genotypes. These genotypes also showed superiority in some agronomic traits compared with the other genotypes. Many significant correlations were observed among agronomic traits each year. On the other hand, no significant correlations were observed between disease intensity variables (DI and DS) and agronomic traits.

\section{INTRODUCTION}

Powdery mildew (PM) of flax (Linum usitatissumum L.) is caused by the obligate parasite Oidium lini Škoric. This fungus infects all the aboveground flax organs including stems, leaves, flowers and capsules. PM occurs annually in all flax production areas in Egypt. Physiological races of the pathogen have not been identified because no differential host lines are available to date (Aly et al., 2001). The importance of this disease has increased probably due to the appearance and rapid distribution of new races capable of attacking the previously resistant cultivars (Aly et al., 1994).

Accurate assessment of losses due to the disease in Egypt has not been reported. However, (Aly et al., 1994) found significant negative correlations between disease intensity ratings and agronomic traits (yield and yield components). In India, (Pandy and Misra, 1993) reported that as the disease increased, yield losses increased ranging from 11.8 to $38.9 \%$. Yield losses were greater when the disease appears earlier in the season. (Ashry et al., 2002) found that total plant length was negatively correlated with each of the early and the late disease incidence, while straw yield per plant was negatively correlated only with the late disease incidence. (Perryan and Fitt, 2000) reported a substantial yield loss in flax due to the decrease in yield components by powdery mildew disease.

Fungicides are currently the only commercially available management practice for controlling the disease and minimizing associated losses in seed and straw yield (Aly et al., 1994 and Mansour, 1998). Complete dependence on fungicides for the disease control carries risks for 
the producers, in that accurate coverage and distribution of fungicides may not be achieved and there are potential problems with correct timing of applications. Furthermore, increasing concern for the environment will likely mean greater regulation of pesticide usage (Pearce et al., 1996).

Use of cultivars with PM resistance can resolve all these problems. Therefore, there is a need to improve PM resistance in flax cultivars through the introgression of resistance genes.

Extensive genetic variation for PM resistance has been identified in some flax populations. For example, (Prasad et al., 1988) evaluated 2822 linseed varieties for rust and PM resistance. The germplasm was classified depending on percentage of leaf area infected/plant. Only, 24 lines were free from both rust and PM, and 17 showed multiple resistance (1-10\% of leaf area infected/plant). In addition, 38 genotypes were free from rust and resistant to PM, and 3 were free from PM and resistant to rust. Sinha et al. (1993) evaluated 313 flax lines for their reaction to rust and PM over three years. 22 showed resistance towards rust and one line showed resistance to rust and PM. (Basandrai et al., 1994) evaluated 200 indigenous and exotic flax genotypes for resistance to PM under field conditions. Twenty-four genotypes were free of infection, and 12 genotypes were resistant to PM. (Mahto et al., 1995) reported a significant variability among 26 flax genotypes in resistance to PM. 11 had above average stability and 7 of these had high yields. (Kar and Lenka, 1998) found that, of 40 linseed were evaluated for their susceptibility to alternaria blight $(A$. lini) and powdery mildew (Oidium lini) in India. There were no resistant genotypes but several were moderately resistant. (Tomas et al., 1999) found that PM occurred in linseed cultivar trails every year from 1993 to 1998 in either the south or east of the UK, but not in the central area. Significant differences in the level of disease occurred between 19 cultivars. These differences were consistent from year to year and from site to site. No cultivar was immune to PM infection, but high levels of partial resistance were recorded. (Zayed and Abou-Zaid, 2002) evaluated 10 flax genotypes to powdery mildew for four years. They stated that, non of the tested genotypes showed satisfactory levels of resistance to the disease. However, cultivar Giza 7, line 366/2/1/2 and line 5 were the least susceptible genotypes. These genotypes showed superiority in some agronomic traits compared with the other genotypes. Many significant correlations were observed among agronomic traits as well as technological traits each year. On the other hand, very few significant correlations were observed between disease intensity variables (DI and DS) and agronomic or technological traits.

(Jyoti-Singh, 2004) found that, a total of 4965 linseed germplasm were filed evaluated for resistance to alternaria blight (Alternaria lini) and powdery mildew (Oidium lini) during the 1991 to 1997 in India. 28 were resistant to both alternaria blight and powdery mildew diseases; 9 were resistant to alternaria blight and moderately resistant to powdery mildew, 51 were resistant to powdery mildew and moderately resistant to alternaria blight; 194 were moderately resistant to both diseases and 54 were moderately resistant to powdery mildew and moderately susceptible to alternaria blight. 
The objectives of the present study were to (1) estimate heritability of powdery mildew (PM) resistance when DI or DS were used as criteria for evaluating resistance, (2) assess resistance to PM of 12 flax genotypes, and (3) determine relationship between disease intensity (DI and DS) ratings and agronomic traits under field conditions.

\section{MATERIALS AND METHODS}

Experiments were conducted over two growing seasons at ELGemmeiza Agricultural Research station in 2005/2006 and 2006/2007. Experiments consisted of a randomized complete blocks design of 4 replicates. Plots were $2 \times 3 \mathrm{~m}\left(6 \mathrm{~m}^{2}\right)$. Seeds of each genotype were sown by hand at the rate of $70 \mathrm{~g} /$ plot. Planting dates were 20 November in first season and 15 November in second season. All cultural practices usually used in flax production were followed. Disease incidence (DI) and disease severity (DS) were related visually on 15 to 30 April in each season. (DI) was measured as percentage of infested plants in a random sample of 100 plants/plot. (DS) was measured as percentage of infected leaves/ plant in a random samples of 10 plants/plot (Nutter et al., 1991).

At full maturity, 10 plants were taken at random from each plot and observations were recorded on individual plants for each of the following agronomic traits :

\section{A- Straw yield and its related characters :}

1- Total plant high $(\mathrm{cm})$ : plant height from the cotyledonary node to the apical bud of each plant.

2- Technical stem length $(\mathrm{cm})$ : the length of the main stem from the cotyledonary node to the first or lowest branching point.

3- Number of fruit branches : total number of fruit branches of plant.

4- Straw yield/plant $(\mathrm{g})$ : weight of the mature air dried straw per plant after removing the capsules.

5- Straw yield/feddan (ton) : estimated based on the area of whole plot.

6- Stem diameter $(\mathrm{cm})$.

\section{B- Seed yield and its related characters :}

1- Number of capsules per plant : number of harvested capsules per plant.

2- Number of seeds per capsule : number of harvested seeds per capsule.

3- Seed yield per plant $(\mathrm{g})$ : weight of harvested seeds per plant.

4- Seed yield per feddan $(\mathrm{kg})$ : estimated based on the area of the whole plot. 
Zayed, S. M. E. et al.

Genetic parameters :

1- Heritability in the broad sense $\left(h^{2}\right)$ was calculated according to the following formula :

Genotypic variance $\left(\sigma^{2} \mathrm{~g}\right)$

Phenotypic variance $\left(\sigma^{2} \mathrm{ph}\right)$

X 100 (Hanson et al., 1956).

Where $\left.\sigma^{2} g=\left(\sigma^{2} e+r \sigma^{2} g\right)-\sigma^{2} e\right] / r$

$\sigma^{2} \mathrm{ph}=\left[\sigma^{2} e+r \sigma^{2} g\right] / r$

2- Genetic advance expected from selection (GA) was calculated according to the following formula :

$$
\left(\sigma^{2} \mathrm{~g} / \sigma^{2} \mathrm{ph}\right) \mathrm{K} \times\left(\sigma^{2} \mathrm{ph}\right)^{1 / 2}
$$

Where $K=2.06$ at $5 \%$ selection intensity (Miller et al., 1958).

\section{Statistical analysis of the data :}

Analysis of variance (ANOVA) was performed on agronomic traits, and disease intensity variables to determine genotype effects. Mean comparisons for variables were made among genotypes by using least significant difference (LSD). ANOVA and correlation analysis were performed by a computerized program (MSTAT-C).

\section{RESULTS AND DISCUSSION}

The present study was conducted in 2005/2006 and 2006/2007 growing seasons (hereafter referred to as years 2005 and 2006, respectively to evaluate the relative resistance of 12 flax genotypes to PM and the effect of the disease on agronomic traits.

Genotype component of variance of DI was significant $(P=0.02)$ in 2005 and very highly significant $(P=0.000)$ in 2006 (Table 1), while that of DS was non-significant in $2005(P=0.12)$ and very highly significant $(P=$ 0.000 ) in 2006. In addition, the genotype component of variance of DI was associated with high heritability and with high genetic advance expected from selection (Table 2). DS, on the other hand, was associated with high heritability and high genetic advance only in 2006. Taken together, these results suggest that considerable progress in breeding for PM resistance could be expected in current breeding program if $\mathrm{DI}$ is used as criteria for evaluating resistance. In addition, from practical point of view, DI is more appropriate than DS for evaluating resistance because it is more precise and more easily acquired (Rouse et al., 1981), which would greatly facililate the selection process. 
Table (1) : Form and expected mean squares for analysis of variance of powdery mildew intensity data from flax genotypes screened for relative resistance under field conditions in EL-Gemmeiza.

\begin{tabular}{|c|c|c|c|c|c|c|c|c|c|}
\hline \multirow[b]{2}{*}{ Season } & \multirow[b]{2}{*}{$\begin{array}{c}\text { Source of } \\
\text { variation }\end{array}$} & \multirow[b]{2}{*}{ D.F. } & \multicolumn{3}{|c|}{ Disease incidence } & \multicolumn{3}{|c|}{ Disease severity } & \multirow{2}{*}{$\begin{array}{c}\text { Expected } \\
\text { mean } \\
\text { square }^{a}\end{array}$} \\
\hline & & & M.S. & $\begin{array}{c}\text { F. } \\
\text { value }\end{array}$ & $P>f$ & M.S. & $\begin{array}{c}\text { F. } \\
\text { value }\end{array}$ & $P>f$ & \\
\hline & Replications & 3 & 24.500 & 0.1241 & $\begin{array}{c}--- \\
\end{array}$ & 376.253 & 1.0520 & 0.3826 & $\sigma^{2} e+g \sigma^{2} r$ \\
\hline $2005 / 2006$ & Genotypes & 11 & 522.106 & 2.6438 & 0.0152 & 600.620 & 1.6794 & 0.1223 & $\sigma^{2} e+r \sigma^{2} g$ \\
\hline & Error & 33 & 197.485 & --- & ---- & 357.698 & --- & --- & $\sigma^{2} e$ \\
\hline & Replications & 3 & 38.688 & 0.6154 & --- & 13.258 & 0.3533 & --- & $\sigma^{2} e+g \sigma^{2} r$ \\
\hline $2006 / 2007$ & Genotypes & 11 & 840.566 & 13.3701 & 0.000 & 827.375 & 22.0462 & 0.000 & $\sigma^{2} e+r \sigma^{2} g$ \\
\hline & Error & 33 & 62.869 & --- & & 37.529 & --- & --- & $\sigma^{2} e$ \\
\hline
\end{tabular}

a $\sigma^{2} e, \sigma^{2} r$ and $\sigma^{2} g$ are variances due to experimental error, replications and genotypes; $g$ and $r$, respectively are No. of genotypes and No. of replications.

Table (2) : Genetic variance (GV), phenotypic variance (PV), heritability in the broad sense, $\left(h^{2}\right)$ and genetic advance expected from selection (GA) for powdery mildew intensity variables of flax genotypes screened for relative resistance under filed conditions in EL-Gemmeiza.

\begin{tabular}{|c|c|c|c|c|c|c|c|c|}
\hline \multirow{2}{*}{ Season } & \multicolumn{4}{|c|}{ Disease incidence } & \multicolumn{4}{|c|}{ Disease severity } \\
\hline & GV & PV & $\mathrm{h}^{2}$ & GA & GV & PV & $\mathrm{h}^{2}$ & GA \\
\hline $2005 / 2006$ & 81.16 & 130.53 & 62.18 & 14.63 & 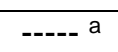 & ---- & ----- & $-\cdots--$ \\
\hline 2006 & 194.92 & .14 & 9252 & 27.63 & 1974 & 7684 & 95.4 & 28. \\
\hline
\end{tabular}

a The parameters were not calculated because of the lack of genetic variation among the tested genotypes.

Natural conditions and levels of inoculum each year resulted in high levels of flax PM on most of the tested genotypes and all the 12 genotypes under evaluation were symptomatic (Table 3). Significant differences in DI occurred among the genotypes; however, some of these differences were inconsistent from year to year, which may indicate the occurrence of genotype $X$ environment interaction. For example, the difference in DI between Sakha 1 and Sakha 2 was nonsignificant in 2005; however in 2006 Sakha 2 sustained statistically significant higher DI than Sakha 1. The difference in DI between line 402/1 and line 424/2/12/1 in 2005 was nonsignificant, while it was significant in 2006. This variation in DI could be due to environmental conditions and the physiological races of the pathogen, which may differ from one year to another (Leath et al., 1991). The results of the present study led us to conclude that most of the tested genotypes did not have satisfactory levels of PM resistance. Moreover, the PM resistance, which was expressed by some of the genotypes, was environmentally sensitive. For example, Sakha 2 was resistant in 2005, while it was 
Zayed, S. M. E. et al.

susceptible in 2006. line 424/2/12/1 was resistant in 2006 and susceptible in 2005.

Table (3) : Powdery mildew intensity variable of twelve genotypes under field conditions in EL-Gemmeiza Agric. Res. Station in 2005/2006 and 2006/2007 growing seasons.

\begin{tabular}{lcccccc}
\hline \multirow{2}{*}{ Genotype } & \multicolumn{2}{c}{ 2005/2006 } & & \multicolumn{2}{c}{$\mathbf{2 0 0 6 / 2 0 0 7}$} \\
\cline { 2 - 3 } \cline { 6 - 7 } & $\begin{array}{c}\text { Disease } \\
\text { incidence }\end{array}$ & $\begin{array}{c}\text { Disease } \\
\text { severity }\end{array}$ & & $\begin{array}{c}\text { Disease } \\
\text { incidence }\end{array}$ & $\begin{array}{c}\text { Disease } \\
\text { severity }\end{array}$ \\
\hline Giza 7 & $53.75^{\mathrm{a}} \mathrm{A}$ & $87.23 \mathrm{~A}$ & & $43.00 \mathrm{BC}$ & $72.49 \mathrm{BC}$ \\
Giza 8 & $44.00 \mathrm{~A}-\mathrm{C}$ & $70.74 \mathrm{AB}$ & & $55.50 \mathrm{~A}$ & $84.64 \mathrm{~A}$ \\
Sakha 1 & $28.00 \mathrm{~B}-\mathrm{D}$ & $58.49 \mathrm{AB}$ & & $19.00 \mathrm{E}$ & $80.41 \mathrm{AB}$ \\
Sakha 2 & $16.00 \mathrm{D}$ & $79.37 \mathrm{AB}$ & & $59.50 \mathrm{~A}$ & $78.24 \mathrm{~A}-\mathrm{C}$ \\
Line 1 & $37.00 \mathrm{~A}-\mathrm{D}$ & $47.89 \mathrm{~B}$ & & $39.00 \mathrm{BC}$ & $42.99 \mathrm{~F}$ \\
Line 3 & $22.50 \mathrm{CD}$ & $69.22 \mathrm{AB}$ & & $23.50 \mathrm{E}$ & $70.64 \mathrm{C}$ \\
Line 5 & $44.00 \mathrm{~A}-\mathrm{C}$ & $63.24 \mathrm{AB}$ & & $49.50 \mathrm{AB}$ & $60.49 \mathrm{D}$ \\
Line 420/153/9/2 & $38.00 \mathrm{~A}-\mathrm{D}$ & $73.43 \mathrm{AB}$ & & $42.25 \mathrm{BC}$ & $75.49 \mathrm{~A}-\mathrm{C}$ \\
Line 420/140/5/10 & $40.75 \mathrm{~A}-\mathrm{C}$ & $61.80 \mathrm{AB}$ & & $36.50 \mathrm{CD}$ & $57.73 \mathrm{DE}$ \\
Line 42/140/5/11 & $22.00 \mathrm{CD}$ & $56.58 \mathrm{AB}$ & & $26.50 \mathrm{DE}$ & $54.74 \mathrm{DE}$ \\
Line 402/1 & $47.00 \mathrm{AB}$ & $52.46 \mathrm{~B}$ & & $50.50 \mathrm{AB}$ & $49.79 \mathrm{EF}$ \\
Line 424/2/12/1 & $34.00 \mathrm{~A}-\mathrm{D}$ & $48.81 \mathrm{~B}$ & & $15.50 \mathrm{E}$ & $45.29 \mathrm{~F}$ \\
\hline
\end{tabular}

${ }^{a}$ Means followed by the same letter (S) are not significantly different $(P \leq 0.05)$ according to Duncan's multiple range test.

In general, Sakha1, line 3 and line 42/140/5/11 were promising for controlling PM because they showed high level of resistance and their resistance was environmentally stable. In addition, they showed superiority in some agronomic traits (Tables 4 and 5).

No significant correlations were observed between disease intensity variables and agronomic traits and all the significant correlations were observed only among the agronomic traits (Tables 6 and 7). This lack of correlation between disease intensity variables and agronomic traits implies that selection for PM resistance would not necessarrily lead to an improvement in agronomic traits and vice versa. In other words, this lack of correlation may complicate flax breeding programs, which aim to the development of PM-resistant cultivars with superior agronomic traits. 
J. Agric. Sci. Mansoura Univ., 33 (4), April, 2008

4-5 
Table (6): Correlation coefficient for agronomic traits and disease intensity variables of 12 flax genotypes infected with powdery mildew under field conditions in 2005/2006.

\begin{tabular}{|c|c|c|c|c|c|c|c|c|c|c|c|c|}
\hline & $\mathbf{X} 1$ & $\mathrm{X} 2$ & X3 & X4 & $\times 5$ & $\mathrm{X} 6$ & $\times 7$ & $\mathrm{X} 8$ & $\times 9$ & X10 & X11 & X12 \\
\hline X1 & & $.082^{\mathrm{a}}$ & -.364 & -.542 & -.284 & -.370 & -.377 & .318 & -.226 & .092 & -.213 & -.398 \\
\hline X2 & & & -.162 & - .209 & -.029 & .133 & .381 & .266 & .298 & -.251 & -.096 & - .327 \\
\hline X3 & & & & $.891^{* \star}$ & .160 & .025 & -.020 & -.136 & .473 & -.027 & .026 & - .202 \\
\hline X4 & & & & & -.094 & .128 & -.113 & -.220 & .349 & -.129 & .015 & -.242 \\
\hline X5 & & & & & & .189 & -.149 & .277 & .512 & .198 & .052 & -.062 \\
\hline X6 & & & & & & & .339 & .371 & .536 & .365 & $.691^{*}$ & .469 \\
\hline $\mathrm{X} 7$ & & & & & & & & $.623^{*}$ & .471 & $647^{*}$ & .355 & .293 \\
\hline X8 & & & & & & & & & .537 & .509 & .202 & $.594^{*}$ \\
\hline X9 & & & & & & & & & & .366 & .400 & .119 \\
\hline $\mathrm{X} 10$ & & & & & & & & & & & .566 & .264 \\
\hline X11 & & & & & & & & & & & & .484 \\
\hline
\end{tabular}

$\mathrm{X} 12$

${ }^{a}$ Linear correlation coefficient is significant at $P<0.05\left(^{*}\right)$.

$\begin{array}{lll}\text { X1 = Disease incidence } & \text { X2 = Disease severity } & \text { X3 = Total plant height }(\mathrm{cm}) \\ \text { X4 = Technical stem length }(\mathrm{cm}) & \text { X5 = No. of fruit branches/plant } & \text { X6 = No. of capsules/plant } \\ \text { X7 = No. of seeds/capsule } & \text { X8 = Stem diameter }(\mathrm{cm}) & \text { X9=Straw yield/plant }(\mathrm{g}) \\ \text { X10 = Seed yield/plant }(\mathrm{g}) & \text { X11 = Straw yield/fed. (ton) } & \text { X12 = Seed yield/fed. }(\mathrm{kg})\end{array}$

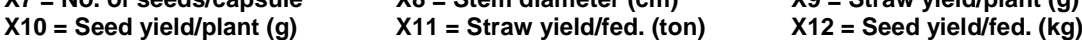

Table (7) : Correlation coefficient for agronomic traits and disease intensity variables of 12 flax genotypes infected with powdery mildew under field conditions in 2006/2007.

\begin{tabular}{|c|c|c|c|c|c|c|c|c|c|c|c|c|}
\hline & X1 & $\mathrm{X} 2$ & $\begin{array}{l}\text { ry n } \\
\times 3\end{array}$ & $\mathrm{X} 4$ & $\times 5$ & $\times 6$ & $\mathrm{X} 7$ & $\mathrm{X} 8$ & $\begin{array}{r}\times 9 \\
\end{array}$ & $\times 10$ & $\begin{array}{l}7 . \\
\times 11\end{array}$ & X12 \\
\hline $\mathrm{X} 1$ & & .281 & -.218 & -.255 & .410 & .107 & -.319 & -.313 & .038 & .237 & -.094 & -.152 \\
\hline X2 & & & -.063 & -.017 & -.184 & -.543 & -.537 & -.442 & - .089 & -.370 & -.144 & -.015 \\
\hline X3 & & & & $.904^{* *}$ & -.129 & - .393 & -.172 & .328 & .002 & $.605^{\star}$ & .025 & -.236 \\
\hline $\mathrm{X} 4$ & & & & & -.329 & -.504 & -.381 & .176 & -.235 & $.692^{*}$ & $\begin{array}{l}-.015 \\
\end{array}$ & -.211 \\
\hline X5 & & & & & & $.790^{\star *}$ & .510 & -.226 & .476 & $.636^{*}$ & - .273 & -.193 \\
\hline X6 & & & & & & & $.750^{* *}$ & .010 & .379 & $.779^{* *}$ & -.367 & 159 \\
\hline X7 & & & & & & & & .303 & 208 & .456 & -.340 & 132 \\
\hline X8 & & & & & & & & & .231 & .050 & .013 & -.206 \\
\hline X9 & & & & & & & & & & $.598^{\star}$ & .282 & .049 \\
\hline 10 & & & & & & & & & & & -.040 & .050 \\
\hline & & & & & & & & & & & & $883^{\star \star}$ \\
\hline & & & & & & & & & & & & \\
\hline
\end{tabular}

${ }^{a}$ Linear correlation coefficient is significant at $P<0.05\left(^{*}\right)$ or $P<0.01\left(^{* *}\right)$.

$\mathrm{X}_{1}=$ Disease inciden $\times 2=$ Disease $\mathrm{X}_{3}=$ Total plant height $(\mathrm{cm})$

$\begin{array}{lll}X 1=\text { Disease incidence } & X 2=\text { Disease severity } & X 3=\text { Total plant height }(\mathrm{cm}) \\ \text { X4 = Technical stem length }(\mathrm{cm}) & X 5=\text { No. of fruit branches/plant } & X 6=\text { No. of capsules/plant }\end{array}$

X7 $=$ No. of seeds/capsule $\quad X 8=$ Stem diameter $(\mathrm{cm}) \quad X 9=$ Straw yield $/$ plant $(\mathrm{g})$

$\mathrm{X} 10=$ Seed yield/plant $(\mathrm{g}) \quad \mathrm{X} 11=$ Straw yield $/$ fed. (ton) $\quad \mathrm{X} 12=$ Seed yield $/ \mathrm{fed} .(\mathrm{kg})$

\section{REFERENCES}

Aly, A.A.; A.Z.A. Ashour; E.A.F. EL-Kady and M.A. Mostafa (1994). Effectiveness of fungicides for control of powdery mildew of flax and effect of the disease on yield and yield components. J. Agric. Sci., Mansoura Univ., 19: 4383-4393.

Aly, A.A.; S.H. Mostafa and M.T.M. Mansour (2001). Effect of powdery mildew disease on yield and yield components of some flax lines. $\mathrm{J}$. Agric. Sci., Mansoura Univ., 26: 7711-7725.

Ashry, N.A.; Mansour, M.T.M.; Aly, A.A.; Zayed, S.M.E. (2002). Genetic studies on powdery mildew resistance of flax, yield and some yield components. Egyptian J. of Agricultural Research, 80(4): 1525-1537. 
Basandrai, D.A.K. Basandrai; S.G. Sethi and S. Bhater (1994). Evaluation of flax (Linum usitatissimum) genotypes for multiple disease resistance. Indian J. Agric. Sci., 64:704-707.

Hanson, J.H.; H.F. Robenson and R.E. Comstock (1956). Biometrical studies of yield in gegregation populations of Korean Lesbedeza. Agron. J., 48: 268-272.

Jyoti-Singh (2004). Field evaluation of linseed, Linum usitatisimum L. germplasm resistance to alternaria blight and powdery mildew diseases. Journal of Oilseeds Research; 21(1): 208-209.

Kar-AK and Lenka-D (1998). Occurrence of alternaria blight and powdery mildew of linseed genotypes in Orissa. Plant Disease Research, 13(2): 160-161.

Leath,S.P.L.Bruckner and J.P.Wilson(1991).Reaction of winter oat germplasm to an epidemic of oat powdery mildew.Plant Dis.,75:807809.

Mahto, J.L.; U. Choudhary and S.N. Singh (1995). Stability and genetic divergence in linseed (Linum usitatissimum L.) under rainfall situation. Indian J. of Agric. Sci., 65: 602-604.

Mansour, M.T.M. (1998). Pathological studies on powdery mildew of flax in A.R.E. Ph.D. Thesis, Zagazig Univ., Moshtohor, 148 p.

Miller, P.A.; J.C. Williams, H.F. Robinson and R.F. Comstock (1958). Estimates of genotypic and environmental variance and covariances in upland cotton and their implications in selection. Agron.J., 50: 126-131.

Nutter, F.W.; Jr. P.S. Teng and F.M. Shoks (1991). Disease assessment terms and concept. Plant Disease, 75: 1187-1188.

Pandey, R.N. and D.P. Misra (1993). Assessment of yield loss due to powdery mildew of linseed. Indian Botanical Reports, 11: 62-64.

Pearce, W.L.; D.A. Van Sanford and D.E. Hersham (1996). Partial resistance to powdery mildew in soft winter wheat. Plant Disease, $80: 1359-1362$.

Perryan, A. and B. Fitt (2000). Effects of diseases on the growth and yield of spring linseed (Linum usitatissimum), 1988-1998. Annals Appl. Biol., 136(3): 197-207.

Prasad, R.; M. Rai and S.A. Kerkhi (1988). Resistance of linseed (Linum usitatissimum) germplasm to rust (Melamposora lini) and powdery mildew (Oidium lini). Indian J. Agric. Sci., 58: 548-549.

Rouse, D.I.; D.R. Mackenzie; R.R. Nelson and V.J. Elliott (1981). Distribution of wheat powdery mildew incidence in field plots and relationship to disease severity. Phytopathology, 71: 1015-1020.

Sinha, J.N.; A.P. Singh; K. Pawan and P. Kumar (1993). Reaction of linseed germplasm to rust (Melampsora lini) and powdery mildew (Oidium lini). J. Appl. Biol., 3: 80-82.

Tomas, J.E.; D.M. Kenyon; E.F. Wedgwood; A. Barrow; S. Cook; C.M. Knott; M.A. Lainsbury and K. Walker (1999). Resistance to powdery mildew (Oidium lini) in cultivars of winter and spring linseed. Aspects of Appl. Biol., 56: 169-172.

Zayed, S.M.E. and T.A. Abou-Zaid (2002). Susceptibility of some flax genotypes to powdery mildew and effect of the disease on yield and yield components. J. Agric. Sci., Mansoura Univ., 27(5): 3073-3087. 
Zayed, S. M. E. et al.

قابلية بعض التراكيب الوراثية للكتان للإصابة بالبياض الاقيقى وتأثير المرض على

المحصول ومكوناته

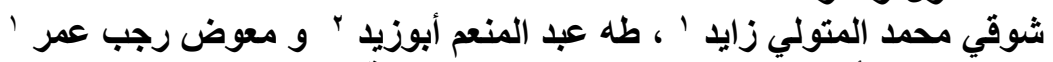

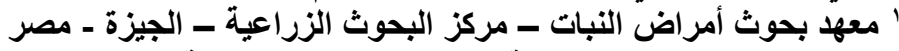

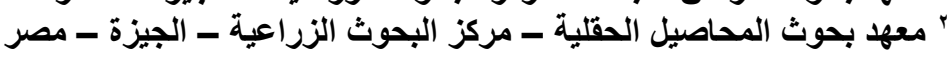

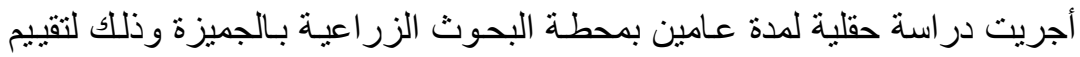

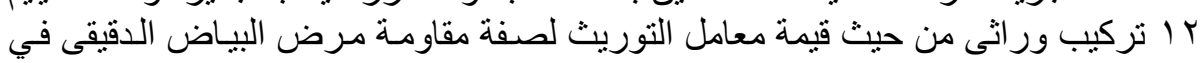

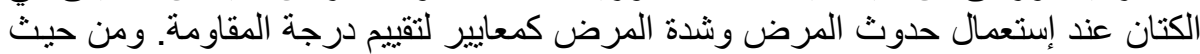

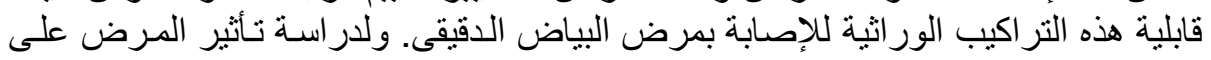

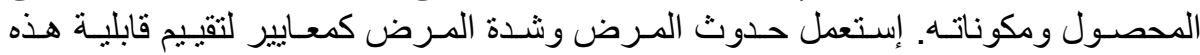

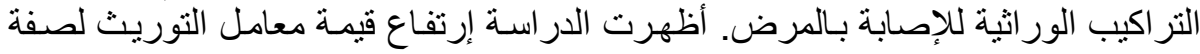

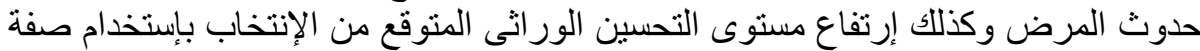

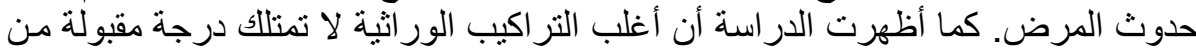

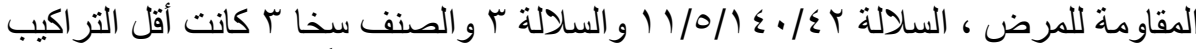

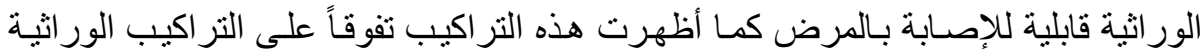

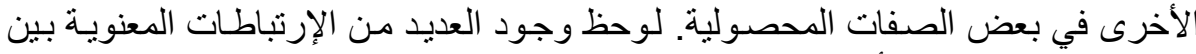

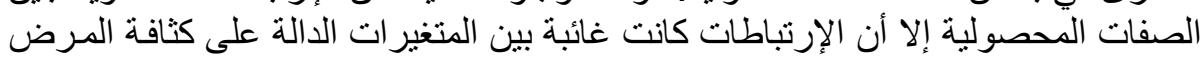
(حدوث وشدة المرض) و الصفات المحصولية. الإنبات 
Table (4) :Agronomic traits of twelve genotypes infected with powdery mildew under field conditions in ELGemmeiza Agric. Res. station in 2005/2006 growing season.

\begin{tabular}{|c|c|c|c|c|c|c|c|c|c|c|}
\hline Genotype & $\begin{array}{c}\text { Total } \\
\text { length } \\
\text { (cm) }\end{array}$ & $\begin{array}{l}\text { Technical } \\
\text { length } \\
\text { (cm) }\end{array}$ & $\begin{array}{c}\text { No. of } \\
\text { apical } \\
\text { branches } \\
\text { per plant }\end{array}$ & $\begin{array}{c}\text { No. of } \\
\text { capsules } \\
\text { per plant }\end{array}$ & $\begin{array}{l}\text { No. of } \\
\text { seeds per } \\
\text { capsule }\end{array}$ & $\begin{array}{l}\text { Stem } \\
\text { diameter } \\
(\mathbf{c m})\end{array}$ & & & $\begin{array}{l}\text { Straw } \\
\text { yield per } \\
\text { feddan } \\
\text { (ton) }\end{array}$ & $\begin{array}{l}\text { Seed } \\
\text { yield per } \\
\text { feddan } \\
\text { (kg) }\end{array}$ \\
\hline $\begin{array}{l}\text { Giza } 7 \\
\text { Giza } 8 \\
\text { Sakha } 1 \\
\text { Sakha } 2 \\
\text { Line } 1 \\
\text { Line } 3 \\
\text { Line } 5 \\
\text { Line } 420 / 153 / 9 / 2 \\
\text { Line } 420 / 140 / 5 / 10 \\
\text { Line } 42 / 140 / 5 / 11 \\
\text { Line } 402 / 1 \\
\text { Line } 424 / 2 / 12 / 1\end{array}$ & $\begin{array}{l}\text { 88.38 B } \\
95.45 \mathrm{AB} \\
94.93 \mathrm{AB} \\
98.22 \mathrm{AB} \\
91.28 \mathrm{AB} \\
97.18 \mathrm{AB} \\
97.97 \mathrm{AB} \\
98.65 \mathrm{AB} \\
104.70 \mathrm{~A} \\
101.6 \mathrm{AB} \\
96.97 \mathrm{AB} \\
95.07 \mathrm{AB}\end{array}$ & $\begin{array}{c}\text { 74.18 B } \\
79.63 \mathrm{AB} \\
79.15 \mathrm{AB} \\
83.63 \mathrm{AB} \\
80.15 \mathrm{AB} \\
83.57 \mathrm{AB} \\
81.50 \mathrm{AB} \\
85.70 \mathrm{~A} \\
85.70 \mathrm{~A} \\
87.65 \mathrm{~A} \\
81.75 \mathrm{AB} \\
80.15 \mathrm{AB}\end{array}$ & $\begin{array}{c}13.90 \mathrm{~A} \\
12.50 \mathrm{~A} \\
9.38 \mathrm{~A} \\
12.82 \mathrm{~A} \\
13.27 \mathrm{~A} \\
10.40 \mathrm{~A} \\
12.75 \mathrm{~A} \\
11.90 \mathrm{~A} \\
10.32 \mathrm{~A} \\
14.45 \mathrm{~A}\end{array}$ & $\begin{array}{l}9.25 \mathrm{~A} \\
7.70 \mathrm{~A} \\
10.68 \mathrm{~A} \\
8.33 \mathrm{~A} \\
7.20 \mathrm{~A} \\
9.30 \mathrm{~A} \\
8.70 \mathrm{~A} \\
7.90 \mathrm{~A} \\
7.70 \mathrm{~A} \\
8.55 \mathrm{~A} \\
7.13 \mathrm{~A} \\
10.00 \mathrm{~A}\end{array}$ & $\begin{array}{l}6.60 \mathrm{~A} \\
6.28 \mathrm{AC} \\
5.83 \mathrm{AC} \\
5.98 \mathrm{AC} \\
5.30 \mathrm{C} \\
6.58 \mathrm{AB} \\
6.18 \mathrm{AC} \\
6.53 \mathrm{AC} \\
6.05 \mathrm{AC} \\
5.53 \mathrm{AC} \\
6.48 \mathrm{AC} \\
5.35 \mathrm{BC}\end{array}$ & & & $\begin{array}{c}0.34 \mathrm{AB} \\
0.41 \mathrm{AB} \\
0.20 \mathrm{~B} \\
0.46 \mathrm{AB} \\
0.40 \mathrm{AB} \\
0.34 \mathrm{AB} \\
0.30 \mathrm{AB} \\
0.24 \mathrm{AB} \\
0.53 \mathrm{~A} \\
0.35 \mathrm{AB}\end{array}$ & $\begin{array}{c}2.28 \mathrm{CD} \\
3.10 \mathrm{BCD} \\
3.88 \mathrm{ABC} \\
3.20 \mathrm{BCD} \\
3.00 \mathrm{BCD} \\
5.14 \mathrm{~A} \\
2.54 \mathrm{BD} \\
2.92 \mathrm{BD} \\
3.20 \mathrm{BD} \\
1.80 \mathrm{D} \\
4.20 \mathrm{AB} \\
2.92 \mathrm{BD}\end{array}$ & $\begin{array}{l}\text { 833.8 CD } \\
844.0 \mathrm{CD} \\
948.0 \mathrm{BD} \\
821.5 \mathrm{CD} \\
876.0 \mathrm{BD} \\
1248.0 \mathrm{~A} \\
972.0 \mathrm{BC} \\
656.0 \mathrm{D} \\
742.0 \mathrm{CD} \\
681.0 \mathrm{CD} \\
1140.0 \mathrm{AB} \\
720.0 \mathrm{CD}\end{array}$ \\
\hline
\end{tabular}

Table (5): Agronomic traits of twelve genotypes infected with powdery mildew under field conditions in ELGemmeiza Agric. Res. station in 2006/2007 growing season.

\begin{tabular}{|c|c|c|c|c|c|c|c|c|c|c|}
\hline Genotype & $\begin{array}{c}\text { Total } \\
\text { length }(\mathrm{cm})\end{array}$ & $\begin{array}{l}\text { Technical } \\
\text { length (cm) }\end{array}$ & $\begin{array}{c}\text { No. of } \\
\text { apical } \\
\text { branches } \\
\text { per plant }\end{array}$ & $\begin{array}{l}\text { No. of } \\
\text { capsules } \\
\text { per plant }\end{array}$ & $\begin{array}{l}\text { No. of } \\
\text { seeds per } \\
\text { capsule }\end{array}$ & $\begin{array}{l}\text { Stem } \\
\text { diameter } \\
\text { (cm) }\end{array}$ & $\begin{array}{l}\text { Straw yield } \\
\text { per plant } \\
\text { (g) }\end{array}$ & $\begin{array}{l}\text { Seed yield } \\
\text { per plant } \\
\text { (g) }\end{array}$ & $\begin{array}{l}\text { Straw yield } \\
\text { per feddan } \\
\text { (ton) }\end{array}$ & $\begin{array}{l}\text { Seed yield } \\
\text { per feddan } \\
(\mathrm{kg})\end{array}$ \\
\hline $\begin{array}{l}\text { Giza } 7 \\
\text { Giza } 8\end{array}$ & $\begin{array}{l}69.03 \mathrm{BD} \\
65.72 \mathrm{CD}\end{array}$ & $\begin{array}{c}57.97 \mathrm{AC} \\
48.58 \mathrm{D}\end{array}$ & $\begin{array}{l}14.00 \mathrm{~A} \\
12.80 \mathrm{~A}\end{array}$ & $\begin{array}{l}9.45 \mathrm{~A} \\
9.18 \mathrm{~A}\end{array}$ & $\begin{array}{l}6.08 \mathrm{AB} \\
6.18 \mathrm{AB}\end{array}$ & $\begin{array}{l}1.83 \mathrm{~A} \\
2.17 \mathrm{~A}\end{array}$ & $\begin{array}{l}0.94 \mathrm{~A} \\
1.16 \mathrm{~A}\end{array}$ & $\begin{array}{l}0.45 \mathrm{~A} \\
0.48 \mathrm{~A}\end{array}$ & $\begin{array}{l}1.99 \mathrm{BC} \\
2.83 \mathrm{BC}\end{array}$ & $\begin{array}{l}727.5 \mathrm{CD} \\
795.0 \mathrm{CD}\end{array}$ \\
\hline
\end{tabular}


Zayed, S. M. E. et al.

\begin{tabular}{|c|c|c|c|c|c|c|c|c|c|c|}
\hline Sakha 1 & $72.65 \mathrm{BC}$ & $62.10 \mathrm{AB}$ & $8.88 \mathrm{~A}$ & $6.00 \mathrm{~A}$ & $5.48 \mathrm{AB}$ & $1.87 \mathrm{~A}$ & $0.80 \mathrm{~A}$ & $0.30 \mathrm{~A}$ & $3.26 \mathrm{AC}$ & $955.0 \mathrm{AC}$ \\
\hline Sakha 2 & $75.07 \mathrm{AB}$ & $65.82 \mathrm{~A}$ & $10.93 \mathrm{~A}$ & $7.33 \mathrm{~A}$ & $5.05 \mathrm{~B}$ & $1.99 \mathrm{~A}$ & $0.97 \mathrm{~A}$ & $0.33 \mathrm{~A}$ & $3.04 \mathrm{AC}$ & $778.8 \mathrm{CD}$ \\
\hline Line 1 & $63.88 \mathrm{D}$ & $51.72 \mathrm{CD}$ & $12.02 \mathrm{~A}$ & $11.32 \mathrm{~A}$ & $5.98 \mathrm{AB}$ & $2.07 \mathrm{~A}$ & $1.22 \mathrm{~A}$ & $0.60 \mathrm{~A}$ & $2.71 \mathrm{BC}$ & $861.3 \mathrm{~B}-\mathrm{D}$ \\
\hline Line 3 & 69.65 B-D & 55.63 B-D & $12.65 \mathrm{~A}$ & $9.50 \mathrm{~A}$ & $6.03 \mathrm{AB}$ & $2.11 \mathrm{~A}$ & $1.54 \mathrm{~A}$ & $0.51 \mathrm{~A}$ & $4.73 \mathrm{~A}$ & $1194.0 \mathrm{~A}$ \\
\hline Line 5 & 70.07 B-D & $55.55 \mathrm{~B}-\mathrm{D}$ & $16.30 \mathrm{~A}$ & $11.82 \mathrm{~A}$ & $6.13 \mathrm{AB}$ & $2.08 \mathrm{~A}$ & $1.26 \mathrm{~A}$ & $0.55 \mathrm{~A}$ & $2.18 \mathrm{BC}$ & $611.3 \mathrm{D}$ \\
\hline Line 420/153/9/2 & $74.20 \mathrm{~B}$ & $61.38 \mathrm{AB}$ & $14.32 \mathrm{~A}$ & $9.50 \mathrm{~A}$ & $5.78 \mathrm{AB}$ & $2.20 \mathrm{~A}$ & $1.50 \mathrm{~A}$ & $0.55 \mathrm{~A}$ & $2.63 \mathrm{BC}$ & $625.0 \mathrm{D}$ \\
\hline Line $420 / 140 / 5 / 10$ & $81.60 \mathrm{~A}$ & $65.55 \mathrm{~A}$ & $13.20 \mathrm{~A}$ & $7.95 \mathrm{~A}$ & $5.93 \mathrm{AB}$ & $2.21 \mathrm{~A}$ & $1.33 \mathrm{~A}$ & $0.36 \mathrm{~A}$ & $3.03 \mathrm{AC}$ & $727.5 \mathrm{CD}$ \\
\hline Line $42 / 140 / 5 / 11$ & $72.40 \mathrm{BC}$ & $58.42 \mathrm{AC}$ & $16.13 \mathrm{~A}$ & $13.50 \mathrm{~A}$ & $6.88 \mathrm{~A}$ & $2.04 \mathrm{~A}$ & $1.19 \mathrm{~A}$ & $0.48 \mathrm{~A}$ & $1.68 \mathrm{C}$ & $665.0 \mathrm{CD}$ \\
\hline Line $402 / 1$ & $71.88 \mathrm{BC}$ & $57.70 \mathrm{AC}$ & $15.58 \mathrm{~A}$ & $11.07 \mathrm{~A}$ & $6.23 \mathrm{AB}$ & $2.08 \mathrm{~A}$ & $1.11 \mathrm{~A}$ & $0.54 \mathrm{~A}$ & $3.81 \mathrm{AB}$ & $1121.0 \mathrm{AB}$ \\
\hline Line $424 / 2 / 12 / 1$ & $75.85 \mathrm{AB}$ & $63.97 \mathrm{AB}$ & $9.45 \mathrm{~A}$ & $8.73 \mathrm{~A}$ & $6.40 \mathrm{AB}$ & $2.66 \mathrm{~A}$ & $0.99 \mathrm{~A}$ & $0.40 \mathrm{~A}$ & $2.54 \mathrm{BC}$ & $700.0 \mathrm{CD}$ \\
\hline
\end{tabular}

